\title{
Atlantis
}

Critical Studies in Gender, Culture \& Social Justice

Études critiques sur le genre, la culture, et la justice

\section{Disciplinary Matters in the Hypatia Controversy}

\section{Namrata Mitra}

Volume 39, numéro 2, 2018

URI : https://id.erudit.org/iderudit/1064074ar

DOI : https://doi.org/10.7202/1064074ar

Aller au sommaire du numéro

Éditeur(s)

Mount Saint Vincent University

ISSN

1715-0698 (numérique)

Découvrir la revue

Citer cet article

Mitra, N. (2018). Disciplinary Matters in the Hypatia Controversy. Atlantis, 39(2), 74-85. https://doi.org/10.7202/1064074ar

\section{Résumé de l'article}

The problem that was thrown up during the Hypatia controversy is a systemic one. I argue that objections to Tuvel's essay regarding its exclusion of perspectives from marginalized points of view should be re-framed as a disciplinary wide issue. I show some ways in which the universal applicability and vantage point often assumed in canonical writings in philosophy, specifically on history and personal identity, emerge from specific contexts and points of view. I demonstrate what is at stake in recognizing the particularity of these contexts. I find that the false dichotomy between seemingly interested "Social justice" scholarship and disinterested inquiries into truth, which I hold perpetuates the disciplinary conditions that produced the Hypatia controversy.
Ce document est protégé par la loi sur le droit d'auteur. L'utilisation des services d'Érudit (y compris la reproduction) est assujettie à sa politique d'utilisation que vous pouvez consulter en ligne.

https://apropos.erudit.org/fr/usagers/politique-dutilisation/ 


\section{Special Section: Research}

\section{Disciplinary Matters in the Hypatia Controversy}

Namrata Mitra is an Assistant Professor of English at Iona College (United States). She earned a Ph.D. degree in Philosophy and Literature at Purdue University in 2012. Her research interests include feminist philosophy, queer theory, and postcolonial literature. Her research examines representations of sexual violence in South Asian literature, comparative postcolonial theories, and the place of shame in nationalist movements.

Abstract: The problem that was thrown up during the Hypatia controversy is a systemic one. I argue that objections to Tuvel's essay regarding its exclusion of perspectives from marginalized points of view should be re-framed as a disciplinary wide issue. I show some ways in which the universal applicability and vantage point often assumed in canonical writings in philosophy, specifically on history and personal identity, emerge from specific contexts and points of view. I demonstrate what is at stake in recognizing the particularity of these contexts. I find that the false dichotomy between seemingly interested "social justice" scholarship and disinterested inquiries into truth, which I hold perpetuates the disciplinary conditions that produced the Hypatia controversy.

Keywords: Hypatia controversy; Rebecca Tuvel; social justice
The controversy following the publication of Re1 becca Tuvel's essay titled "In Defense of Transgenderism," published in Hypatia (March 2017), revealed longstanding schisms in the discipline of philosophy. In her essay, Tuvel identifies an inconsistency between the social acceptance of "transgenderism" and "transracialism" by citing the examples of Caitlyn Jenner and Rachel Dolezal. These figures function as a springboard for Tuvel's discussion of the conventions of gender transition and racial passing. She argues that these identities are analogous and since one is irrefutably acceptable the other should be considered acceptable too. ${ }^{1}$ Animating the controversy were two opposed yet oddly overlapping responses: while some claimed that Tuvel perpetuated a harmful epistemic method by not including the perspectives and scholarship of black and transpersons ("Open Letter to Hypatia," 2017; Winnubust 2017), others held that the essay did not cause exceptional harm because the article's methods reflect the norms of the discipline (Weinberg 2017a). Interestingly, both responses suggest that Tuvel's essay did not aberrate from but rather exemplified the genre of philosophical analysis. The implications of this shared view, however, are understood in vastly different ways by these two responses. In this essay, I explore the stakes of this overlapping yet dissenting recognition of the disciplinary nature of Tuvel's article.

Philosophy, like all disciplines, has a form. ${ }^{2}$ That is, in order to be recognized as an argument in the discipline, an essay needs to observe certain formal requirements (Dotson 2012). Yet the formal elements of the discipline remain unmarked as attributes of the form, so though they are present they may not be reckoned. They remain unrecognizable as discipline-specific. There is much at stake in naming and studying the form of the discipline, and the Hypatia controversy is 
a productive site at which to draw out the formal attributes of philosophy, making them more recognizable and therefore more open for accountability. In this essay, I discuss two disciplinary attributes that are at the heart of the canonical and contemporary methods, attributes which are prevailing but undertheorized in the controversy: the claim to universality and the claim to abstraction. Moreover, in what follows I unpack the effects of these formal conventions on ideas of personal identity and of history. Finally, I argue that contrary to claims, these seemingly abstract and universal ideas carry significant traces of their particular context and that overlooking the details of its context is harmful. This is the key point of my essay. The open letter, which was one of the driving engines of the controversy, demanded a retraction of Tuvel's article on the grounds that it caused epistemic harm ("Open Letter"). Even before the letter was delivered to the journal, the associate board apologized for the harms caused by the article (Weinberg 2017b). This specific charge of harm needs to be taken very seriously in the context of a discipline whose formal norms have a long-standing record of epistemic harm. Tuvel's essay observes the disciplinary forms of philosophy. I argue that to isolate the critique of this epistemic method to Tuvel's essay alone and to demand its retraction overlooks how her argument is produced within the intellectual tradition of Western philosophy. In short, if there was a problem brought into focus during the Hypatia controversy, it was a systemic one. Accordingly, what is central to my own argument is that Tuvel's article should be taken as an example of disciplinarity in philosophy, rather than a sole or outlier example. I take the controversy to be an invitation to scrutinize philosophyqua-discipline. The call for retraction, on the terms of my argument, becomes itself a perplexing expression of disciplinarity, rather than an incisive critique of Tuvel's project. The very charge of "harm" itself becomes an expression of philosophical commitment: to think with and against, in the name of cross- and inter-disciplinary forms and methods.

\section{Abstraction and Universality as Disciplinary Form}

What kinds of knowledge are made possible, or conversely, rendered impossible, when an inquiry acknowledges its ties to the particular context out of which it emerged? This question is an important one, even if it is often evaded by knowledge-seekers, and even if the inquiry in question is seeking to invoke "universal" ideas such as justice or beauty. In the discipline of philosophy, it is quite common to pursue abstract inquiries rigorously, while at the same time to bracket the particular context(s) of the philosophical "problem" under investigation. If anything, this lack of attentiveness to the context of the problem is insisted upon in the name of good philosophical virtues like clarity, objectivity, and the universality of legitimate knowledge. Put more strongly, questions such as "what is identity?" or "what is history?" are considered for inclusion in the corpus of philosophical knowledge only after the particularities of any discernible context have been sloughed off to reveal a universal question. In simple terms, the philosophical method consists of bracketing unnecessary contextual details in order to work out the answer to the problem in the abstract. Yet when this method plays out in the context of professional philosophy, it is usually not able to achieve such abstractions. Indeed, one of the aims of this article is to demonstrate how philosophical ideas, particularly social and political theories, fail to leave or abstract away from their contexts, despite vested interests that they do so. This failure emerges, in particular, out of a twofold tendency: a given context is assumed universal and this assumption remains unacknowledged (and most likely unrecognized) by the philosopher.

What is at stake in assuming one's own particular context to be universal?3 Consider how the following method of abstraction is not unique to Tuvel's essay, but central to writings in the discipline of philosophy: for the purported sake of clarity of examination, a problem, including a social-political problem, is placed into an abstract realm. In that realm, the argument is entertained, explored, and concluded without 
any significant interruption from historical, literary, and anthropological discourses. Once the problem is resolved, its conclusion is taken back out of the abstract sphere and assumed to be universally "applicable," sometimes with minor adjustments to accommodate the differences between various social and material contexts. This method is as old as philosophy itself: we see it in Plato in the fourth century BCE, Thomas Hobbes in the seventeenth century, Immanuel Kant in the eighteenth century, George Friedrich Hegel and John Stuart Mill in the nineteenth century, John Rawls in twentieth century, and in every major canonical thinker in the history of philosophy.

Here, I want to be clear that I am not making a case against abstraction. Abstraction is necessary for thinking and for conscious movement. To ask us to abandon it would be as if asking us to forgo thought itself. It would amount to asking people to write laws without an idea of justice, to make moral decisions without a conception of good and evil, to multiply and divide without numbers, and to never create a new recipe or make a map. Therefore, I am certainly not asking us to stop thinking, counting, cooking, and travelling. Instead, I am asking us to open that abstract realm of philosophical thought further, and to contaminate that sphere with contradictory ideas and discourses from other disciplines, before settling upon our questions and, certainly, before arriving at our conclusions. Such cross- and inter-disciplinary contamination is especially urgent when we contemplate our social world and ourselves within it, as, for example, when we consider arguments about identity.

Let us explore how the subject of "personal identity" has been taken up in the discipline of philosophy in relation to the claims of abstraction and universality. Traditionally, this question asks: On what basis can I say that I am the same person today as I was yesterday and will be tomorrow? What is the criterion for claiming that one is the same self over time? The usual suspects for this criterion have been the soul, the body, one's mind, or a combination of each of them. John Locke, writing in the late seventeenth century, invokes the now famous example of the prince and the cobbler whose bodies swap their "souls carrying the consciousness" (Locke 1689). Even if the body of the cobbler were to be recognized by others as that of the cobbler, he would still be the prince because he would have the consciousness of the prince. "Consciousness alone unites actions into the same Person," states Locke definitively (1689). In a bid to emphasize that it is not the substance that determines the sameness of the person over time, he engages in another thought experiment and asks us to imagine our little finger being cut off. As long as our consciousness remains intact we would continue to be the same person, despite the missing little finger. Over three hundred and fifty years later, Daniel Dennett, in a work of philosophical science fiction, takes this imaginative exercise about the loss of the finger and extends it to the loss of the entire body. He tells an exciting story about a scientist hired by NASA to recover a dislodged nuclear warhead buried underground. His body and brain were separated. When his body died, another body was created, and his memories were recreated on a computer. At different points, different bodies and brains were hooked up. We are left asking: What constitutes the self? The brain, body, memories, or a combination of each of these? Both Locke and Dennett's work on personal identity appear in many introductory philosophy anthologies and are widely taught in freshman courses across North America. The mind-body dualism and the puzzles they present in this story are framed in the terms laid out already in Locke's writings: imaginary musings, which are not tied to a specific "real" world context, lead to conclusions that are understood to be universally applicable to all contexts.

Feminist philosopher Susan Brison pursues a related but different line of inquiry. She poses questions of personal identity in the specific context of trauma. Survivors of war and violence who are suffering trauma often claim that they died in the war, or that they miss the person they used to be $(2003,38)$. Brison takes up the question about the criteria of the continued self by situating it in the specific, named 
context of those who have written about the effects of trauma on themselves. She wonders what it means to claim that one's continued identity is situated in memory when one's memory has been partly erased or re-arranged, and when flashbacks seem like the present. To the survivor of trauma, one's body (which is inseparable from one's mind) also does not present itself as a viable site for the continued self. Brison, herself a survivor of assault, found that in experiences of trauma, the discreet categories in the mind-body dualism seem like a myth rather than convincing and robust descriptions of human life. Many traditionally assigned psychic states, Brison writes, present themselves as bodily symptoms and vice versa $(2003,44)$. Eventually, Brison turns to the narrative self as the possible basis on which the self can be represented as continuous before and after the experience of trauma. One of the effects of past theorization of personal identity, which looks to otherworldly settings rather than to narratives by people who speak about having lost their selves and having experienced the very loss of continuity in question, is that philosophy stops being an effective resource for those who need it the most.

Though the experience of trauma is common in our society, and survivors speak of it in terms of outliving their former selves and inquire what it means to no longer be the person they once were, philosophers have largely overlooked these writings in their discussions of personal identity. As Brison notes:

Philosophers writing about the self have, at least since Locke, puzzled over such questions as whether persons can survive the loss or exchange of their minds, brains consciousness, memories, characters, and/or bodies. In recent years, increasingly gruesome and high-tech thought experiments involving fusion, fission, freezing, dissolution, reconstitution, and/or teletransportation of an individual have been devised to test our intuitions about who, if anyone, survives such permutations. Given philosophers' preoccupation with personal identity in extreme, life threatening, and possibly self-annihilating situations, it is odd that they have neglected to consider the accounts of actual trauma victims who report that they are not the same person they were prior to their traumatic transformations. (Brison 2003, 3839)

Brison explains this phenomenon by saying that philosophers are trained to look away from the "messy real world" in favour of a fantasized "neater" and "controllable" realm as the preferred setting for contemplating philosophical problems (Brison 2003, 39). Perhaps this disciplinary move is based on the assumption that imagined otherworldly contexts can proximate a universal context by virtue of its seeming removal from contingent historical and social conditions in this world. After all, the thought experiment of a person undergoing brain-body transplants, or duplicating his memories on a computer, is assumed to be universally applicable because it is not particular to any specific person's "real" experience. In fact, it may even be tempting to think of these fantastical settings as universal because one can easily swap out one socially assigned identity, such as gender, race, or religious identity, for another. We have seen such a move in the recent trend in philosophy wherein the traditionally assigned pronoun "he" is swapped for "she," leaving everything else about the argument intact. However, what these nearly self-annihilating mind-body thought experiments tend to miss is that the protagonists in these examples have already been imagined as invulnerable to trauma and immune from psychological dissociative states, even while they are subject to morbid experiments. In personal identity thought experiments, trauma has traditionally been both an impossibility and an improbability. Therefore, it turns out that these examples are not based on a universally applicable context at all, but rather are limited to a figure who is invulnerable to trauma despite repeated violent experiences. The conditions of possibility and impossibility in thought experiments are determined by the limits of the author's imagination, which in turn are shaped by the author's vantage point, existing knowledge, curiosity or its lack, and experience. The realm of an abstract thought experiment is not universal but is rather particular to the author's context and worldview. 
However, the disciplinary form of philosophy has traditionally demanded that the particular context be generalized and presented as universal.

Another reason to choose examples distant from the contemporary social context of the intended reading audience has to do with the perception that details can compromise philosophical rigor. If an argument is embedded in a particular social context, its focus on questions about an abstract philosophical problem might be derailed by debates about the details of class, race, sexuality, and gender that were only meant to be incidental and not essential to the examples. Mary Midgley once pondered what details would best serve her argument against ethical relativism. She states that the criteria for illustrative details should be something "remote" enough so that "we shall probably find it easier to think calmly about it" (1981, 2014,11 ). (She eventually settles on an erstwhile Japanese samurai practice, a practice remote from herself and her readers). The social and geographical location of Midgley and her intended audience is a particular one, and it is relevant to the search for an example that is "remote" from it. Already, such an example is not universal but particular, and ironically relative to the location of the audience. Of course, "remote" is an entirely relative term as it depends upon the vantage point of the viewer. Making a case for an objective, universal moral standard through examples which must be "remote" so that different audiences situated in different places can agree to its universality carries within it much comic irony. At the same time, such a contradiction is worthy of serious philosophical exploration and can be carried out by interrogating the social location, context, and vantage point of the inquirer.

One of the most widely circulated objections to Tuvel's "In Defense of Transracialism" was that the essay's argument was not sufficiently situated in accounts of the lived experiences, histories, and perspectives of marginalized groups. As this section seeks to demonstrate, such objections would be more fruitful if they were situated within a broader critique of modern Western philosophy. The generalization of one's own context and vantage point as abstract and universal is a long-standing formal practice in the discipline, despite being critically challenged by many readers writing from within and outside of the discipline. While the discussion of personal identity shows the effects of abstraction and universality on a microlevel analysis of the self, we may ask how these formal methods shape our understanding of more macro and global institutions, and narratives of our social-political past.

Much of the field of postcolonial/decolonial theory has been dedicated to searching out a beneficial legacy of the universal (e.g., democratic equality and justice) to guide systems of law and political institutions and sorting this from a harmful legacy (e.g., universal history and universal progress) that is routinely used to justify state violence. It helps to turn to Dipesh Chakaravarty, who makes an important intervention into the formal conventions of the philosophy of history. He shows that major European philosophers who espoused Enlightenment ideas of democracy and freedom as a universal good also accepted, if not promoted, the European expansion of empires in South Asia and Africa. Chakrabarty draws our attention specifically to John Stuart Mill, a philosopher who held these two seemingly opposing beliefs. On the one hand, Mill claimed that the best sort of government was a democratic one while, on the other hand, he believed that Asians and Africans were not yet ready or sufficiently civilized to self-govern (Chakrabarty 2000, 8). How are such contradictory claims theoretically sustained in philosophy? According to Chakrabarty, both claims build upon a historicist construction of Europe's past. Here is how this construction works: narrators of European history divvy up their past into specific periods or eras, such as "medieval," "modern," "feudal," and "capitalist." Each period is identified by specific characteristics in its modes of thought and production, its values, and its cultural system, as though the other periods are discreet and separate spheres with little iteration of earlier cultural ideas and practices. These periods or eras are then placed into a progressive order whereby one period indicates "backwardness" and another signifies 
"progress." This allows for the construction of a historical narrative whereby feudalism progresses to capitalism, and medievalism progresses to modernity. However, major Enlightenment thinkers did not acknowledge how these historicist categories were based on narratives of Europe's intellectual and material past. Instead, they framed it as the fixed trajectory of all world history and world future. Conveniently, by their own measure, Europeans had nearly reached the teleological end of universal history. Having arrived there first, it fell upon them to guide their colonies towards humanity's foretold destiny. With this new understanding of world history, one that is not particular to any context because it has been abstracted away from all contexts, it is no longer a contradiction to proclaim both democracy as the highest form of government, and Europe as the right or best imperial ruler of South Asia and Africa. In fact, such a rule fully accords with democracy because it enables the colonizers to teach the colonized how to rule themselves.

It is important for Chakrabarty that his readers recognize how the phenomena of political modernity, such as civil society, the liberal state, government bureaucracy, and citizenship are the products of Europe's intellectual and material past (2000, 9). However, the particularity of modernity's historical context had to be erased in order to make modernity the teleology of world history and Europe's advancement towards that universal goal. Not only is that context decontextualized, but the specific vantage point of the philosopher-historian is also erased. When the historicist story of Europe's past is assigned a universal status, its thinkers are simultaneously conferred an omniscient point of view that allows them to look into the past, present, and future of the entire world from everywhere and nowhere.

What is at stake in representing our past and future in abstract and universalizing forms? These forms, that continue to thrive in the discipline of philosophy, have wreaked great epistemic and material harms the world over, particularly in the Global South. For over two centuries now, the story of man- kind's "progress" has become the sedimented grounds on which Europe and later the United States have legitimized imperialism and routine wars. More recently, in 2001, the US military launched "Operation Enduring Freedom” by driving tanks into Afghanistan. To aid these efforts, images of Afghan women in burqas were widely circulated in the US and were effective in erasing narratives of economic and social damage caused by twenty years of covert US war in Afghanistan, and in creating a chivalric narrative of rescuing Afghan women (Mahmood 2005; Abu-Lughod 2013). The US government congratulated itself for bringing freedom and modernity to the women (United States, 2004). Soon after the invasion, The New York Times contributed to this idyllic picture of Afghanistan having nearly arrived at the teleological end of history. Women, liberated and joyous, are now "uncovering their faces, looking for jobs, walking happily with female friends, on the street, and even hosting a news show, on Afghan television," announced an essay unironically titled "Liberating the Women of Afghanistan" (The New York Times 2001). The idea of universal history hurtling towards modernity with the US at the helm continues to function as justification for invasions and imperialism. Moreover, as Saba Mahmood points out, such a narrative succeeds in erasing accounts of the devastated living conditions of Afghan women due to the war.

The formal attributes of philosophy need to be seriously reckoned with in the context of its harms. It is in this regard that we should receive our inheritance of social and political philosophy with a critical perspective, principally by asking how we can draw on its nourishing legacy without reiterating its devastating effects. [4] An understanding of long-standing disciplinary forms can also guide how we critically unpack the Hypatia controversy. The open letter does not call for an engagement with Tuvel's essay but rather its retraction on the grounds that "[i] ts continued availability causes harm." Such a framing of the charge effectively lets the discipline off the hook but places Tuvel at the center, making her answerable for centuries-old epistemic harms wreaked by claims to abstraction and universality. ${ }^{5}$ 
Questions that seek to interrogate the theoretical implications of assumed universal contexts are often treated within the discipline of philosophy as a special interest topic. Inquiries about the particular context of philosophical questions or the vantage point of the inquirer have not seemed to affect either the contents of the philosophical canon or how it is commonly taught in American classrooms. For instance, John Stuart Mill's support for colonization is usually categorized as a discreet topic with no bearings on his ethical and political writings. Mill is taught and often written about as though his point of view does not come from a specific location and time but from a space-less and timeless context. Or, think about how common it is to teach Immanuel Kant's writings on ethics and politics as universal questions emerging from universal contexts, without interrogating how they were affected by his anthropological writings on race. Kant's writings, like all other writings in the philosophical canon, emerge from very specific historical contexts; this is overlooked, however, when organizing the canon into the curriculum. As a discipline, philosophy has traditionally been uncurious about the historical and social context of its own canon, and it continues to remain so in many of its areas. Accordingly, it is all the more important to create conditions in which to foster difficult and productive disagreement.

At the heart of Tuvel's essay lies an analogy between the way that gender identity and racial identity are constituted and claimed. Tuvel seeks to make both identities performatively constituted in order to allow for more freedom in how they can be claimed. Representation of race as a socially constructed identity that can be challenged performatively is both a common trope and a common subject of contention in literature on passing. The trope itself is not new. However, the more worrisome aspect of Tuvel's essay is that all racial passing is cast as the same. Tuvel abstracts some principles of racial passing regardless of which identity one has been socially assigned, which identity one seeks to claim, or how one seeks to claim it. She dubs this process "transracialism" (a term originally coined by Janice Raymond to deny recognition of transgender identity). The framework of Tuvel's iteration of "transracialism" cannot account for the differences between black-to-white passing and white-to-black passing in present-day America or its past. What kinds of knowledge are erased when we seek to abstract the idea of race, racial identity, and racial passing by overlooking the particular context of different racial identities, their histories, locations, and the power relations among and within the groups?

\section{Forms of Identity Analogies}

One question that the Hypatia controversy has returned to the forefront of disciplinary conversation is: How should we understand identity analogies? This seemed to be the major point of contention on social media during the controversy, with some calling for an end to all identity analogies. How can we negotiate this demand in the context of existing feminist discussions on identity and their analogies? Different forms of identity analogies have been constructed towards different political ends in the US; sometimes to secure rights for marginalized groups and at other times to limit, if not deny, rights to marginalized groups. ${ }^{6}$ Since the 1960 s, civil rights arguments in the American judiciary have been made in courtrooms through "like race arguments" or analogies with existing anti-discrimination rights for racial minorities who are recognized as the first constituency to gain protections and freedoms through identity-based rights. ${ }^{7}$ One productive way to respond to the Hypatia controversy involves sorting through some forms of identity analogy to unpack the freedoms and harms they enable.

Black feminists such as Patricia Hill Collins and bell hooks have argued that analogical arguments about discrimination faced by "women" and "people of colour," predominantly made by white feminists, fail to recognize the intersections between the identity categories. Such analogies effectively erase the experiences and struggles that are particular to women of colour. The thinkers demand a recognition of identity 
categories as intertwined and varied when mapped on a person. The form of intersecting categories does not readily yield identity analogies. Consider how an analogical argument which asserts that women face employment discrimination like people of colour and so deserve similar legal protections appears to require that one imagine the category of women as white and ignore the intersection of "women of colour" who, by virtue of belonging to both categories, are not like either category but are both.

Although the form of intersecting identities may seem resistant to an analogical relationship, it is possible to arrange the analogical argument in a way that the point of intersection lies at the center of the frame, rather than outside of it. For instance, a case seeking protection against discrimination based on sexual orientation can be made with an analogy to racial discrimination by focusing explicitly on queer persons of colour who need legal protection as queer persons of colour. Serena Mayeri explores the example of Pauli Murray, an African American lawyer who formulated an influential form of race and gender analogy, in her case for the inclusion of women under Title VII of the Civil Rights Act in 1964. She pointed to the position occupied by black women who, at the time, were supposedly entitled to protection against discrimination (as a racial minority) but were denied protection against discrimination (as women). How is a black woman who is repeatedly denied employment able to tell if it is based on her race, her gender, or both? Until she is protected from discrimination against both, she will continue to suffer discrimination, which may very well be on the basis of her race (from which she is ostensibly protected), or from her race and gender simultaneously. Murray invoked the figure of "Jane Crow" to draw on a "race-sex parallel to highlight [. . . ] that the eradication of racial discrimination was impossible without the inclusions of black women in employment protections" (Mayeri 2001, 1045).

One of the main limitations of analogical arguments as the basis for seeking redress is that the legal remedy can only be modelled on existing protections of the group to which one will be compared. While identity analogies are unavoidable in civil rights advocacy, the identity with which one is yoked in an analogy is open for strategic alterations. The stakes are very high in choosing the identity group (whose claims of injury and redress are already recognized) for the analogical argument. Attempts to make new pairings of identity groups in the service of political advocacy and social acceptance, as Tuvel does, are already a part of the disciplinary tradition. Once again, Tuvel's essay observes an established practice in feminist philosophy. For example, we may turn to feminist philosopher Chris Cuomo who argues that queer acceptance should be secured through an analogy with the right to religious practice rather than the prevailing comparisons with racial minority rights (2008). The particular pairing of the analogy matters because laws against racial discrimination in the US are based on a conception of racial identity that is unchanging and immutable (i.e. identity as who one is), whereas laws for exercising religious freedoms are based on a conception of identity that requires affirmation and practice (i.e. identity as what one does). Since homophobia often takes the form of "love the sinner, hate the sin," she calls for a social re-conceptualization of queer identity that is understood in terms of queer acts. By calling for changes in the identity pairing from racial identity to religious identity, she is inviting her readers to change how sexual orientation is ontologically understood from what one is to what one does.

In addition to the specific liberatory possibilities shown by Cuomo, let us consider other urgent reasons for moving away from formulating identities as fixed and immutable. Writing for an audience of civil rights advocates, Janet Halley asks, "[h]ow should a critical politics of the law think about the possible coercive effects of identity-based advocacy?" (2000, 44). After a 1938 landmark judgement against racial discrimination claimed that race was an "immutable" identity situated in "a discreet insular community," subsequent anti-discrimination cases for other marginalized groups, particularly gays and lesbians, have cited similar conditions. However, as Halley reminds 
us, an analogy can often work both ways. For instance, if one claims that $\mathrm{B}$ is like $\mathrm{A}$, on the grounds of $\mathrm{X}$ and so should enjoy the same rights as $\mathrm{A}$, then one is also implicitly claiming that $\mathrm{A}$ is also like $\mathrm{B}$ in terms of X. Typically, the effect of this has been that judges who oppose the rights of B start making the requirement of $\mathrm{X}$ more and more stringent (Halley 2000). This has had negative effects on both group $A$ and group $B$. In the response to gay rights advocacy using "like race" arguments, judges who opposed gay rights sought to narrow the criteria of immutability, which in turn affected ongoing and future race-based anti-discrimination cases. The criteria of "immutability" became more rigorously applied, which means that, in the courtroom, racial identity was being constructed as fixed and unchanging. Accordingly, any mutable aspects of one's identity were edged out from the category of race. This implies that racial discrimination (such as prohibiting black women employees from wearing braids or telling Latino employees that they cannot speak in Spanish at work) becomes morally acceptable if one can assimilate (Halley 2000). This also affects groups of "theoretically mutable characteristics" such as those fighting against discrimination on the basis of fatness (Halley 2000,66 ). As a result of the more rigorous criteria for the "like race" analogy, it becomes more difficult to seek protection under the reified requirement of immutability because it implies that if it is possible for one to lose weight, then discrimination based on weight should not be protected by the law; one should simply lose the weight. How did all of this affect queer communities who were seeking rights through "like race" arguments? Queer groups began policing identity-based claims within the community. If one has access to gay rights by establishing that one is either born gay or straight, then ways of desiring which exceed the borders of those two categories such as bisexuality, queerness, and pansexuality become subject to shaming from within the community, in addition to ostracism from outside.

Of course, this does not mean that group B (from the analogy of $B$ is like $A$ ) should now suffer in silence and stop fighting for their legal rights (Halley
2000). Rather, the solution might lie in how and when we make our identity-based analogies. Halley suggests that while we cannot (and should not) abandon identity analogies in the courtroom, there is an imperative to make them more carefully. She encourages us to forgo those forms of identity analogies that are based on how identities might be ontologically constituted (e.g., B is constituted like A), as it has been done by Cuomo, Tuvel, and much philosophical writing on social ontologies, but rather make them based on the similarity of the discrimination faced by the two groups; the harms that B suffers are similar to the harms that A suffers, or there is a similarity in the structure of oppression acting on both groups, or there are similar factors at the root of their oppression. ${ }^{8}$

\section{Concluding Reflections on the Hypatia Controversy}

It has been over a year since the Hypatia controversy pushed Tuvel, the journal, and contemporary feminist philosophy into the glaring public spotlight. Perhaps the most alarming aspect of it all was the widely supported public letter that demanded retraction rather than critical engagement with Tuvel's article. Public letters have typically been used as an instrument of writing back to power. This public letter, however, staged an inversion of the genre: it was crafted and supported by leading figures of disciplinary and institutional authority and the criticism focused entirely on the work of an untenured philosophy professor. It is a chilling spectacle to witness another junior feminist colleague being publicly shamed (Weinberg 2017a) rather than engaged with and mentored for her perceived academic shortcoming by senior feminists.

Another unsettling aspect of the entire controversy is that it is often named after Rebecca Tuvel, e.g., "The Tuvel Affair." This moniker misleadingly suggests that Tuvel's argument is such an aberration from the discipline that it produced a controversy. It is worth reiterating that Tuvel's article is not atypical within the context of the discipline from which it emerged. As I 
have argued earlier in this essay, her argument observes the norms of philosophy, namely, claims to universality and abstraction, which should be examined as disciplinary forms in relation to the harms they cause. The origin of the controversy, however, seems to lie less in the unusualness of the article and more in the escalating public response to academic writings on social media. In this case, it began with rumblings on Twitter and Facebook, which galvanized into the now-famous public letter with 830 signatories. Before the letter could be delivered, the associate board of editors apologized for publishing Tuvel's article. As the article had already passed the journal's peer review process and had already been published, this move was unprecedented in the discipline. Then, philosophy blogs and national newspapers picked up the story and dubbed it a controversy. Naming the controversy after Tuvel places her at the center of the frame all over again, and risks a dangerous precedent for emerging scholars in the discipline.

\section{Endnotes}

1. One of the main critiques of Tuvel's article, namely, its exclusion of the socio-historical contexts and writings of the very marginalized groups who both constitute the object of analysis and are deeply affected by such theoretical inquiries, is essentially related to broader questions about the discipline of philosophy. Sabrina Hom shows that the elision of two centuries of African American literature on passing in Tuvel's essay is not new in feminist philosophy: Tuvel's omissions heed an existing tradition of exclusionary citational practices established by senior feminist philosophers, including Christine Overall and Cressida Heyes. Through a close reading of literature on passing, Hom demonstrates that philosophical questions that are posed on the basis of speculations about passing and not on the basis of its two-hundred-year-old literary history are often rendered moot, if not misleading, due to the absence of relevant citations and readings. For instance, Heyes (2006) frames the main challenge of passing as a moral issue about dishonesty, rather than about the loss of com- munity and family for the marginalized community and the passer, as it has been framed in African American literature. Likewise, Overall's question about how "passing might amount to betrayal of group identity" (Hom 2018, 35) overlooks the legacy of that question in contemporary debates about mixed-race identity claims in the twenty-first-century United States census. Such a critique also overlooks the possibility of someone who passed and drew on their new positions to engage in politics towards racial justice (Piper 1991, 9). All of these questions have been fiercely debated in literature from the perspectives of those who have been most affected by them. Hom contends that by overlooking the literature on passing, one runs the risk of asking questions that prioritize "the position of a white gaze" (Hom 2018, 34).

2. Caroline Levine (2015) unpacks the ways in which forms/structures impose upon us to organize, or disorganize our social, political, and cultural worlds. I draw on her work to think about the formal dimensions of the discipline of philosophy.

3. Feminist philosophers have long explored the problems of assuming the universal category of citizen, human, or person as a cisgender man. Susan Mendus (2001) argues that democracy does not allow for equal participation of men and women when the citizen is imagined as a man. Debra Bergoffen (2003) has illustrated the importance of thinking of the category of human as differently sexed in order to make recognizable sexual violence during war as a crime against humanity.

4. Examples of such work in philosophy include the Creolizing The Canon Series (NY: Rowman \& Littlefield) edited by Jane Ann Gordon and Neil Roberts in which questions about race, empire, and theories of history inform close readings of canonical figures such as Hegel and Rousseau.

5. A similar argument is made by Amy Olberding (2017), who in a blog post on Feminist Philosophers, makes a plea to "to stop symbolically conscripting 
Rebecca Tuvel into the role of personifying all of [the] systemic issues that attach to the profession at large."

6. See Mayeri (2001) for a critical legal history of "gender is like race" analogies. This analogy was instrumental in the advocacy for white women's rights in Antebellum America, and later as a feminist legal strategy from the 1960s in cases such as inclusion of "gender" in title VII, and then again during the 1990s in arguments for legal remedies for Violence Against Women Act. Not coincidently, the same analogy was politically mobilized in the opposite direction in the nineteenth century by defenders of slavery and of white women's subordination within patriarchy.

7. Halley (2000) critically unpacks gay rights cases that rely on "like race" arguments to demonstrate which have more coercive effects would need to be rethought. However, she finds that calling an end to identity analogies is off the table since identity analogies is the only recognizable form of civil rights advocacy in the US. As she explains, "the ethical inquiry [into 'like race' arguments] has to be conducted, I think on an assumption that asking the advocates of gay, women's, or disabled people's rights to give up 'like race' similes would be like asking them to write their speeches and briefs without using the word 'the.' 'Like race' arguments are so intrinsically woven into American discourses of equal justice that they can never be entirely forgone. Indeed, analogies are probably an inescapable mode of human inquiry and are certainly so deeply ingrained into the logics of American adjudication that any proposal to do without them altogether would be boldly utopian. ... ." (46)

8. For a more detailed discussion on different forms of analogical argument see Serena Mayeri (2001).

\section{References}

Abu-Lughod, Lila. 2013. Do Muslim Women Need Saving? Cambridge, MA: Harvard University Press.

Bergoffen, Debra. 2003. "Towards a Politics of the Vulnerable Body.” Hypatia 18(1): 116-134.

Brison, Susan J. 2003. Aftermath: Violence and the Remaking of a Self. Princeton: Princeton University Press.

Chakrabarty, D. 2000. Provincializing Europe:

Postcolonial Though and Historical Difference. New Jersey: Princeton University Press.

Cuomo, Chris. 2008. "Claiming the Right to be Queer." In The Feminist Philosophy Reader, edited by Alison Bailey and Chris Cuomo, 241-49. New York: McGraw Hill Higher Education.

Daily News. 2017. "Statement from Hypatia Board Regarding Tuvel Controversy.” May 18, 2017.

Dennett, Daniel. 1978, 2007. "Where am I?” In Delight in Thinking: An Introduction to Philosophy Reader, edited by Steven D. Hales and Scott C. Lowe. McGraw-Hill: New York.

Dotson, Kristie. 2012. "How is this Paper Philosophy?" Comparative Philosophy 3(1): 3-29.

Halley, Janet. 2000. "Like Race Arguments." In What's Left of Theory: New Work on the Politics of Literary Theory, edited by Judith Butler, John Guillory, Kendall Thomas. 40-74. NY: Routledge.

Hom, L. Sabrina. 2018. “(Dis)-engaging with Race Theory: Feminist Philosophy's Debate on 'Transracialism' as a Case Study." Philosophy Today 62(1): 31-50.

hooks, bell. 2014. "Racism and Sexism: An Issue of Accountability." In Ain't I a Woman: Black Women and Feminism. 119-149. NY: Routledge

Issue $39.2 / 2018$ 
Levine, Caroline. 2015. Forms: Whole, Rhythm, Hierarchy, Network. Princeton: Princeton University Press.

Locke, John. 1689, 1996. An Essay Concerning Human Understanding: In Four Books. Indianapolis: Hackett Press.

Mahmood, Saba. 2005. Politics of Piety: The Islamic Revival and the Feminist Subject. Princeton: Princeton University Press.

Mayeri, Serena. 2001. "'A Common Fate of Discrimination': Race-Gender Analogies in Legal and Historical Perspective." The Yale Law Journal 6: 1045-1087.

Mendus, Susan. 2001. "Losing the Faith: Feminism and Democracy." In Democracy: A Reader, edited by Ricardo Blaug and John Schwarzmantel, 324-25. New York: Columbia University Press.

Midgley, Mary. (1981, 2014) “Trying Out One's Own Sword." In The Moral Life: An Introductory Reader in Ethics and Literature reprinted in 2014, 5th Edition. New York: Oxford University Press.

The New York Times. 2001. "Liberating the Women of Afghanistan.” November 24, 2001.

https://www.nytimes.com/2001/11/24/opinion/liber ating-the-women-of-afghanistan.html

Olberding, Amy. 2017. "Symbolic Conscription." Feminist Philosophers: News Feminist Philosophers Can Use (blog). Accessed September 15, 2018. https://feministphilosophers.wordpress.com/2017/05 /02/symbolic-conscription/

“Open Letter to Hypatia." 2017.

https://archive.is/lUeR4/. Last modified 2 May 2017.

Piper, Adrian. 1991. "Passing for White: Passing for Black.” Adrian Piper. Accessed April, 152018.
http://www.adrianpiper.com/docs/Passing.pdf

Tuvel, Rebecca. 2017. "In Defense of Transracialism." Hypatia 32 (2): 263- 278.

United States. The White House. 2004. "Rights and Aspiration of the People of Afghanistan." July 8, 2004. https://georgewbush-

whitehouse.archives.gov/infocus/afghanistan/200407 08.html

Weinberg, Justin. 2017a. "Hypatia Controversy Updates (Updated).” Daily Nous, May 9, 2017. 2017b. "Statement from Hypatia Board Regarding Tuvel Controversy." Daily Nous, May 18, 2017.

Winnubust, Shannon. 2017. "Why Tuvel's Article So Troubled its Critics." The Chronicle of Higher Education, May 8, 2017. 